DOI 10.31558/2519-2949.2020.2.17

УДК 351.86:32(470)

ORCID ID: https://orcid.org/0000-0003-3230-6082

Самарець Г. І., Воєнно-дипломатична академія імені Свгенія Березняка

\title{
ПОЛІТИКА РОСІЙСЬКОЇ ФЕДЕРАЦІї ЩОДО ПРИДНІСТРОВСЬКОГО КОНФЛІКТУ. УКРАЇНСЬКИЙ ВИМІР
}

У статті розкриті основні заходи зовнішньої політики Російської Федерації (РФ) стосовно Республіки Молдова (РМ) та Придністровського регіону РМ. Спрямованість заходів політики РФ з даного питання має чітку мету: за допомогою всіх доступних політичних інструментів утримати РМ в сфері свого геополітичного впливу. Керівнищтво РФ вважає за необхідне утримувати ситуачію довкола Придністров'я у «замороженому стані», чим забезпечує контроль зовнішньої політики РМ та блокування європейських та євроатлантичних уподобань та прагнень РМ. Реалізуючи зазначені заходи, РФ також забезпечує свою легітимну військову присутність в регіоні через участь у миротворчій операиії з підтримання миру в Придністровському регіоні РМ.

Автор пропонує розглянути заходи зовнішньої політики РФ стосовно РМ та Придністров'я не в історичній площині, а через політичну, економічну та військову спрямованість иих заходів, розділивши їх на дві суттєві групи. Перша з них характеризується створенням та розвитком конфлікту до стадії збройного протистояння з подальшим його підтриманням у активній фазі до стану втрати власних інтересів об'єктом геополітичного тиску Росії. Друга - завершенням стадії збройного протистояння і переведенням конфлікту до стадї̈ «замороженого» через початок тривалого переговорного процесу з подальшим його утриманням в такому стані якомога довгий час.

3 огляду на тотожність європейського та євроатлантичного вибору РМ і Украйни, наявність спільного кордону, не виключається можливість застосування РФ напрачьованого в Придністровському регіоні РМ політичного інструментарію щщодо України. Отже природно постає питання попередження можливих загроз національній безпеці Украйни та недопущення відповідними державними органами України розвитку ситуаиії з гібридною агресією Російської Федерачії проти Украӥни за російським сиенарісм.

Порівняння заходів політики РФ щодо України у період від початку збройної агресії і дотепер з заходами політики РФ щодо РМ та Придністров'я дає змогу визначити місие російського сиенарію, де зараз перебуває Україна, та передбачити шляхи його розвитку $i$, відповідно протидії.

Ключові слова: Придністровський регіон Республіки Молдова, Російська Федерація, зовнішня політика, національна безпека України.

Постановка проблеми в загальному вигляді. У зовнішній політиці Російської Федерації (РФ) на пострадянському просторі спостерігається стійка тенденція до створення конфліктів та утримання їх у замороженому стані. До сумнозвісного переліку конфліктів належать: НагірноКарабаський (між Азербайджаном та Вірменією), Абхазький і Південно-Осетинський (між сепаратистськими утвореннями в цих регіонах Грузії i iï конституційною владою), Придністровський (між сепаратистським псевдодержавним утворенням в цьому регіоні Молдови і конституційною владою Республіки Молдова (РМ). Окремо в цьому переліку слід виділити агресію РФ проти України.

Кожен із інсценованих Росією конфліктів у силу низки об'єктивних причин має свої, притаманні тільки йому, особливості, пов'язані з історичними та етнічними чинниками, що притаманні кожному регіону конфлікту, геополітичними прагненнями РФ в регіоні та геополітичною ситуацією в світі на час початку конфлікту.

Разом з тим у кожному конфлікті РФ застосовує типовий набір інструментів своєї зовнішньої політики. Визначимо російський політичний інструментарій на прикладі заходів зовнішньої політики РФ щодо Придністровського регіону РМ. 
3 огляду на ситуацію з агресією РФ проти України, використання Росією певних інструментів у власній зовнішній політиці щодо «заморожених конфліктів» може нести загрозу національній безпеці України.

Зв'язок проблеми з важливими науковими i практичними завданнями. Питання, що розглядається, безпосередньо пов'язано з практичною діяльністю відповідних державних органів України, спрямованою на визначення конкретних завдань та їх виконання в інтересах забезпечення національної безпеки держави.

Аналіз останніх досліджень та публікацій. Проблема врегулювання Придністровського конфлікту існує не одне десятиліття. Ї̈ дослідженням займалися іноземні автори, такі як А. Макаркін, В. Сокор, 3. Тодуа, О. Нантой. Питаннями воєнної безпеки України займався вітчизняний дослідник Г. Перепелиця. Однак, можливе використання Росією проти України напрацьованих, та свого часу успішно реалізованих щодо РМ і Придністров'я заходів зовнішньої політики недостатньо досліджено з точки зору загрози національній безпеці України.

Мета статті - на основі аналізу політики РФ щодо «замороженого конфлікту» в Придністровському регіоні РМ визначити заходи зовнішньої політики РФ, що можуть становити загрози національній безпеці України.

Виклад основного матеріалу. Історичний досвід перебігу «заморожених конфліктів» на пострадянському просторі (зокрема у Придністровському регіоні РМ) 390-х років минулого сторіччя і до теперішнього часу, сучасна політика РФ щодо України, дають підставу зробити висновок про те, що для реалізації своїх геополітичних інтересів, Росія, через використання національного сепаратизму, створює потенційні конфліктні ситуації, сприяє їх розвитку, переростанню у фазу збройного протистояння, з подальшим іiі припиненням через впровадження російської миротворчої місії й переведенням конфліктів та тривалому підтриманню їх у «замороженому стані». Всі російські сценарії таких конфліктів мають типові заходи. Для більшого розуміння розділимо їх на дві групи.

Перша група заходів - характеризується ініціацією та ескалацією конфлікту до стадії збройного протистояння 3 подальшим його підтриманням у активній фазі аж допоки об'єкт геополітичного тиску Росії не почне поступатися власними інтересами на користь останньої. До цієї групи заходів політики РФ віднесемо такі:

- підтримка сепаратистського руху у Придністровському регіоні, де на той час розміщувалися війська підконтрольні владі колишнього СРСР (на території РМ базувалася 14 армія збройних сил СРСР зі штабом у м. Тирасполь);

- мілітаризація регіону через розподіл військового майна, озброєння та військової техніки 14-ї армії між сторонами майбутнього конфлікту за територіальною ознакою (Молдові було передано озброєння та військову техніку військових частин, що базувалися на території РМ, а придністровські сепаратисти отримали частину зброї військових частин 14-ї армії, що базувалися в регіоні);

- створення, за підтримки 14-ї армії, незаконних військових формувань, що не тільки були забезпечені російським озброєнням, а й укомплектованими військовослужбовцями РФ;

- провокація збройного конфлікту між сепаратистським режимом у Придністровському регіоні і владою РМ через розгортання масштабної інформаційної війни проти РМ та систематичне залякування населення Придністров'я жахами «насильницької румунізації»;

- втручання підрозділів 14-ї армії в перебіг збройного конфлікту на території РМ на боці придністровського сепаратистського режиму, що забезпечило його військову перемогу;

- пропозиція РФ щодо посередництва в конфлікті між сепаратистським режимом i конституційною владою та вдале ситуативне використання недосвідченості тодішньої влади РМ, що призвело до схвалення Молдовою російської пропозиції і перетворило Росію на посередника у врегулюванні конфлікту, забезпечивши їй цим вагомий вплив на внутрішньополітичні процеси в РМ та можливість тиску на офіційний Кишинів у питаннях визначення ним зовнішньополітичних пріоритетів.

Друга група заходів характеризується завершенням стадії збройного протистояння i переведенням конфлікту до стадії «замороженого» через початок тривалого переговорного процесу з подальшим його утриманням в такому стані якомога довгий час. До цієї групи заходів віднесемо такі:

Заходи політичного характеру:

- блокування переговорних ініціатив інших держав, зокрема України, ОБСС та США 
(липень 2002 р.), України (план Ющенка, 2005 - 2006 р.), ігнорування вже існуючого переговорного формату, такого як «5+2» та намагання звести його нанівець через витіснення сторін 3 переговорного процесу [1,2];

- висування численних планів врегулювання конфлікту що сприяють реалізації геополітичних інтересів РФ в регіоні, але $є$ неприйнятними для сторін конфлікту, що фактично робить переговорний процес «вічним»:

- «план (меморандум) Примакова» - підписання Президентом РМ та головою адміністрації Придністров'я «Меморандуму про основи нормалізації відносин між РМ і Придністров'ям» (08.05.1997 p., Москва) [3]. Цей документ заслуговує на окрему увагу, оскільки він містить ряд суттєвих пасток для РМ. По-перше, в ньому РМ та Придністров'я фігурують як дві рівноправні сторони переговорного процесу. А це означає, що всі рішення мають прийматися за взаємним погодженням сторін. По-друге, у меморандумі з'явилося поняття «країн-гарантів», у ролі яких фігурують Росія та Україна, - саме їм меморандум надає право бути гарантами досягнутих угод. Потретє, запроваджено використання поняття «спільної держави», в рамках якої РМ і Придністров'я мають будувати свої стосунки. Саме ця особливість меморандуму поставила придністровське врегулювання в глухий кут, оскільки і РМ і Придністров'я тлумачать поняття «спільної держави» виключно кожен по-своєму. У розумінні Придністров'я «спільна держава» - формується на основі конфедеративних принципів взаємовідносин з Молдовою і передбачає право Тирасполя самостійно формувати державні органи законодавчої і виконавчої влади, проводити власну зовнішню й внутрішню політику, особливу фінансову політику, мати свої збройні сили, митні органи, органи державної безпеки і правопорядку. Такий підхід не сприймається Кишиневом, оскільки фактично руйнує цілісність держави. Поняття «спільної держави», на переконання Кишинева, передбачає державу з унітарним територіально-державним устроєм, в якому Придністров'я розглядається як складова частина єдиної держави. Проте позиція «ПМР» є непохитною через російську військову присутність в регіоні. Цілком очевидно, що така формула «вирішення» придністровського конфлікту влаштовує насамперед РФ. Оскільки, враховуючи ресурсний потенціал Росії в регіоні, наявність в Придністров’ї значної кількості російськомовних громадян та етнічних росіян, Росія може забезпечити більш високий рівень зайнятості і життя населення на лівобережжі Дністра, а отже може маніпулювати цією «спільною державою» виходячи з власних інтересів;

- «план Примакова», 2000 р.; передбачав створення на основі так званої «Придністровської Молдавської Республіки» («ПМР») і РМ договірної федерації. Цей план передбачав і участь України в урегулюванні конфлікту - але на другорядних ролях, лише як партнера, що підтримає «ідеологічну ініціативу» РФ, однак він не став вирішальним для долі РМ та невизнаної «ПМР»;

- «план Козака» (2003 р.) передбачав створення федеративної держави - Республіки Молдова, одним із суб'єктів якої мало стати Придністров'я із збереженням російської військової присутності;

- «план Ю. Зубакова» (2007р.) передбачав відмову від федеративного устрою держави, проведення виборів, пропорційний розподіл мандатів у парламенті РМ та портфелів у кабінеті міністрів, утримання від вступу до НАТО та у розміщенні військових баз на території РМ [4];

- «план Козака 2» (2007-2008 р.) в основу якого було покладено ідею проведення реінтеграції Молдови під егідою РФ. Передбачалось, що конфедеративне об'єднання РМ і Придністров'я відбудеться за умови контролю Кремля за внутрішньополітичною ситуацією в Молдові і гарантії Кишиневом нейтрального статусу держави.

Після провалу «плану Козака» (2003 р.) миротворча політика РФ щодо врегулювання конфліктів на пострадянському просторі зазнала кардинальних змін. Керівництво Росії, продовжуючи генерувати плани врегулювання придністровського конфлікту, вдалося до вже неодноразово випробуваних засобів тиску i шантажу на країни так званого «близького зарубіжжя» задля поновлення свого домінування на всьому пострадянському просторі чи, перефразовуючи В. Путіна, «продовження виконання своєї цивілізаційної місії на континенті Євразія» [5] для «подолання» наслідків «найбільшої геополітичної катастрофи XX століття», якою російський президент вважає розпад СРСР [5]. Ці зміни в політиці РФ вплинули й на ії взаємини з Молдовою. Серед заходів зовнішньої політики РФ щодо Придністров'я з'явились такі:

- систематичне, починаючи з 2005 р., розхитування політичної ситуації в РМ, особливо напередодні президентських чи парламентських виборів та почергова підтримка то партії комуністів Молдови (ПКМ) то демократичних сил [6];

- проведення у Придністров’ї референдуму (вересень 2006 р.), 97\% - учасників якого підтримали ідею незалежності «ПМР» і її наступне приєднання до Росії [6]; 
- запровадження та підтримка в Придністров'ї інституту російського громадянства (станом на 2000 р., понад 60 тис. жителів регіону отримали громадянство РФ. 324.07 .2020 р. передбачається запровадження спрощеного порядку отримання російського громадянства [7], що може відкрити нові можливості для мешканців придністровського регіону зрілого віку, багатьом 3 яких було відмовлено в отриманні російського громадянства, тому що вони вже мають громадянство РМ);

- запровадження в Придністров ї загальновживаної мови - російської, повної відповідності освіти, культури правових основ суспільства російським стандартам [8];

- запровадження верховенства російських законів на території регіону, підігрівання перспектив входження Придністров'я до складу РФ [8-10];

- демонстрація російської турботи про населення Придністров'я (надання РФ жителям «ПМР» щомісячних надбавок до їхніх зарплат та пенсій в еквіваленті 15 дол. США, здійснення поставок природного газу, періодичне надсилання «гуманітарних конвоїв»);

- реалізація заходів, що націлені на недопущення євроатлантичного та європейського спрямування політики РМ [8].

Заходи економічного характеру:

- введення РФ чисельних економічних обмежень у двосторонніх економічних відносинах з РМ (починаючи 32004 р. поступово згорталися російсько-молдовські економічні зв'язки, у 2005 р. 3'явилася заборона на ввезення до РФ плодоовочевої продукції, у 2006 р. припинено імпорт до РФ молдовських вин та коньяків, експорт яких складає важливу частину доходів країни) [11]. Як наслідок скуповування російським бізнесом за заниженими цінами збанкрутілих молдовських підприємств та подальше відновлення постачання продукції до РФ підприємствам з російським капіталом;

- створення ситуації, за якої РМ має розраховуватись за послуги чи товари, які не замовляла i не використовувала. Так, поставляючи природний газ до Придністровського регіону, рахунки за нього РАТ «Газпром» виставляє офіційному Кишиневу, який, як відомо, не визнає «ПМР». Це означає, що за поставлений росіянами газ наразі не розраховується ніхто: Тирасполь тому, що не має на це коштів, а Кишинів не планує сплачувати за товар, який не купувався ним безпосередньо. В Кремлі воліють не нагадувати Тирасполю про його борг, сподіваючись, що у разі реінтеграції Придністров'я до складу Молдови, цей борг визнає офіційний Кишинів, а у випадку входження Придністров'я до складу Росії, борг «ПМР» буде списано;

- експансія російського бізнесу у придністровську економіку, мета якої - взяття під контроль економіки «ПМР» [11]. Безпосереднім наслідком російської економічної експансії в Придністров’і стало те, що найпривабливіші об'єкти економіки були скуплені оптом і за значно заниженими цінами. Так, наприклад, Молдавська ГРЕС у Придністров’і, що забезпечує електроенергією усю Молдову, продана дочірньому підприємству РАТ «ЕЕС Росії» - «Інтер РАТ» за 20 млн. дол. США, при тому, що ії ринкова вартість становила близько 150 млн. дол. У 2007 р. власністю «Уральської сталі» російського олігарха А. Усманова став Молдавський металургійний завод в м. Рибниця, експорт продукції якого забезпечує $30 \%$ бюджетних надходжень Придністров'я. Крім того, російські бізнесмени стали власниками таких придністровських підприємств, як винзавод «Букет Молдавії», Бендерський шовковий комбінат, взуттєва фабрика «Флоаре», завод з виробництва зброї «Прилад》 тощо.

Заходи воєнного характеру:

- використання спецслужб РФ для відновлення [12]. збройної фази конфлікту у 1992 році, що призвело до припинення існуючого на той час чотиристороннього процесу врегулювання конфлікту за участю РМ, Придністров 'я, України, Румунії і виключення останньої із нього;

- введення до зони конфлікту частин збройних сил (3С) РФ для здійснення миротворчих функцій та створення «зони безпеки» на адміністративному кордоні між Придністровським регіоном та рештою території РМ;

- подальше використання РФ своїх ЗС разом з розташованим у Придністров'ї миротворчим контингентом, для посилення свого геополітичного впливу в регіоні;

- укладення угоди між РФ та РМ щодо виведення 14-ї армії (переговори щодо виведення 14-ї армії тривали з серпня 1992 р. по жовтень 1994 р.). В результаті часткової реалізації Росією угоди загальна чисельність угрупування іiї військ та техніки зменшилася, однак термін остаточного виведення російських військ з території Придністров'я наразі залишається невідомим, а знищення величезного арсеналу боєприпасів, розташованого поблизу ст. Ковбасна, що знаходиться за декілька кілометрів від державного кордону України з РМ, продовжується й донині [13]. 
Окрім того, втілюючи в життя перелічені заходи, РФ здійснює процеси консолідації російського суспільства через створення образу ворога в особі незалежних пострадянських республік. Їм посилено «інкримінуються» не тільки удавані порушення прав російськомовного населення, але й відкрите декларування прозахідної орієнтації власного державного розвитку. Ідеологічні кліше неосталіністського спрямування та так звані «скрепи» кремлівської пропаганди часів «холодної війни» успішно реанімуються у масовій свідомості i вже суттєво впливають на політичну самосвідомість та поведінку пересічних росіян. Особливо наполегливо експлуатується ідея витіснення Росії з територій, що історично перебували під іiі впливом. Усе це породжує агресивні настрої в російському суспільстві.

Як бачимо, широкий спектр заходів зовнішньої політики РФ, який вона застосовує, фактично дозволяє їй реалізовувати свої геополітичні інтереси в регіоні та ще й сприяти цим у вирішенні своїх внутрішньополітичних проблем.

Зважаючи на збройну агресію РФ проти України і ту ситуацію коли Росія всіляко намагається утримати Україну на орбіті своїх геополітичних інтересів, наявність спільного кордону між Україною і РМ, етнічну і культурну близькість населення України та РМ, великої актуальності для національної безпеки України набуває врахування досвіду так званої «миротворчої діяльності» РФ щодо Придністров'я.

Молдовський політик О. Нантой, виказує сподівання, що українське суспільство і політики не повторять «наших» помилок і не попадуть в той же капкан, в якому Молдова «безпомічно борсається вже скоро тридцять років» [14].

Виходячи з вищезазначеного, можна стверджувати, що у розвитку агресії проти України РФ буде діяти за своїм типовим сценарієм і використовувати відносно України випробуваний в інших пострадянських державах типовий набір заходів зовнішньої політики. Тому врахування цього фактору дозволить відповідним українським державним органам успішно протидіяти заходам політики РФ стосовно України, що можуть нести загрозу ії національній безпеці.

За умови порівняння заходів зовнішньої політики РФ стосовно України у період з початку іiі агресії проти нашої держави з заходами зовнішньої політики РФ відносно РМ та Придністров'я, стає очевидним на якій фазі зовнішньополітичного сценарію щодо України знаходиться РФ, і відповідно можна передбачити іiі наступні кроки, а у разі наявності загрози цих заходів національній безпеці України - заздалегідь їм протидіяти відповідним чином. А саме:

- щодо заходів політичного характеру - РФ використала майже всі типові сценарії першої групи заходів і всіляко намагається організувати визнання конституційною владою України законності сепаратистських утворень у Донецькій та Луганській областях та усадити владу України і сепаратистські режими за стіл переговорів, тобто, забезпечити перехід до втілення в життя другої групи типових заходів своєї зовнішньої політики. Отже, можливими подальшими заходами РФ політичного характеру можуть бути блокування існуючих переговорних ініціатив (мінський, нормандський формати), що не відповідають геополітичним прагненням РФ та пропонування якихось нових форматів, де буде забезпечена «миротворча» роль РФ та розстановка політичних пасток на кшталт меморандуму Примакова 1997 р. » [3];

- щодо заходів економічного характеру - РФ вже намагалася затягнути Україну в пастку надуманих боргів за спожитий газ населенням та підприємствами тимчасово окупованих територій Донецької та Луганської областей. Підприємства на тимчасово окупованих територіях банкрутують та знищуються або набувають нових власників. РФ введено численні економічні обмеження щодо України (заборона постачання промислових та продовольчих товарів). Отже, можливими подальшими заходами РФ економічного характеру можуть бути посилення економічної експансії в українську економіку через скуповування промислових підприємств представниками російського бізнесу, не відкрито, а приховано, через підставних осіб;

- щодо заходів воєнного характеру - для легалізації своїх збройних сил на території України РФ всіляко намагається організувати введення ЗС РФ до тимчасово окупованих територій України у Донецькій та Луганській областях в якості миротворчого контингенту. Отже, можливими подальшими заходами РФ воєнного характеру можуть бути посилення інтенсивності бойових дій на лінії збройного протистояння в районі операції об'єднаних сил для подальшої активації «миротворчої» ролі РФ.

Висновки. Політика РФ відносно Придністровського регіону Республіки Молдова спрямована на підтримання «керованої нестабільності» в регіоні якомога довше. 
Визначення інструментів зовнішньої політики РФ щодо придністровського «замороженого конфлікту» дозволяє визначити можливі загрози національній безпеці України у разі розвитку гібридної агресії РФ проти України за російським сценарієм.

Завчасне зосередження уваги відповідних державних органів України на кроках з упередження можливих дій РФ у проведенні ескалації своєї агресії в Україні, надасть змогу нейтралізувати негативні наслідки заходів зовнішньої політики РФ стосовно України.

Перспективи подальших досліджень: визначення завдань відповідним державним органам України для упередження та нейтралізації загроз національній безпеці України від заходів зовнішньої політики РФ.

\section{Бібліографічний список:}

1. Макаркин Алексей. План Ющенко и план Козака. URL: //www.rian.ru/analytics/20050615/40526451 (дата звернення: 22.01.2020).

2. Стенограмма ответов Министра иностранных дел России С.В. Лаврова на вопросы СМИ в ходе участия в 14-ом заседании СМИД ОБСЕ, Брюссель, 4 декабря 2006 года. URL: http://www.mid.ru/brp_4.nsf/sps /6BF4942CDFCA982AC325723A00526638 (дата звернення: 29.01.2020).

3. Меморандум об основах нормализации отношений между Республикой Молдова и Приднестровьем (подписан в г. Москва 08.05.1997). URL: http: //www.lawmix.ru/abro.php?id=6291. (дата звернення: 29.01.2020).

4. Socor Vladimir. Voronin pressured to accept settlement plan for Transnistria.

URL: http://www.jamestown.org/edm/article.php?article_id=2372098\%5C\%22l\%22 (дата звернення: 30.01.2020).

5. Путін розповів про завдання Росії і найбільшу геополітичну катастрофу XX століття.

URL: http://ua.korrespondent.net/world/256784-putin-rozpoviv-pro-zavdannya-rosiyi-inajbilshu-geopolitichnukatastrofu-hh-stolittya (дата звернення: 12.02.2020).

6. Тодуа 3.Д. Россия в Молдавии: вернуть инициативу. Россия в глобальной политике. Москва. 2007. № 1. C. $154-162$.

7. О гражданстве Российской Федерации. Федеральній закон от 31.03.2002, № 62-Ф3.

URL: http:/consultant.ru/document/cons_doc_LAW (дата звернення: 24.05.2020).

8. Путін натякнув, що не проти приєднати Придністров’я. URL: http://espreso.tv/news/2014/04/17

/putin_natyaknuv_scho_ne_proty_pryyednuvaty_prydnistrovya (дата звернення: 30.01.2020).

9. Придністров'я проситься в Росію. URL: http://www.pravda.com.ua/news/2014/03/18/7019364/ (дата звернення: 25.03.2020).

10. Приднестровье обратилось к России за признанием. URL: http://tiras.ru/tema-dnja/40150-pridnestroveobratiloskrossii-za-priznaniem-i-prisoedineniem-k-rossii.html (дата звернення: 25.04.2020).

11. Гамова Светлана. Кусок Молдавии уходит в собственность России. URL: http://www.ng.ru/cis /2006-04-17/1_moldavia.html (дата звернення: 27.04.2020).

12. Нантой Оазу. Приднестровский конфликт и взаимоотношения Молдовы и Украины. Контекст. 2001. № 10. C. $22-34$.

13. Перепелиця Г.М. Воєнна безпека України на межі тисячоліть. URL: http://www.niss.gov.ua/book /bezpeka/index.htm (дата звернення: 19.12.2019).

14. Не попадите в капкан, в котором барахтается Молдова. URL: http://google/arm/s/www.radiosvoboda.org (дата звернення: 25.05.2020).

\section{References:}

1. Makarkin Aleksey. Plan Yuschenko i plan Kozaka. URL: //www.rian.ru/analytics/20050615/40526451 (Access date: 22.01.2020).

2. Stenogramma otvetov ministra inostrannyih del Rossii S.V. Lavrova na voprosyi SMI v hode uchastiya v 14-om zasedanii SMID OBSE OБSE, Bryussel, 4 dekabrya 2006 goda.

URL: http://www.mid.ru/brp_4.nsf/sps/6BF4942CDFCA982AC325723A00526638 (Access date: 29.01.2020).

3. Memorandum ob osnovah normalizatsii otnosheniy mezhdu Respublikoy Moldova i Pridnestrovem (podpisan

v g. Moskva 08.05.1997). URL:http: //www.lawmix.ru/abro.php?id=6291. (Access date: 29.01.2020).

4. Socor Vladimir. Voronin pressured to accept settlement plan for Transnistria.

URL: http://www.jamestown.org/edm/article.php?article_id=2372098\%5C\%221\%22 (Access date: 30.01.2020).

5. Putin rozpoviv pro zavdannya Rosiyi i najbilshu geopolitichnu katastrofu XX stolittya.

URL: http://ua.korrespondent.net/world/256784-putin-rozpoviv-pro-zavdannya-rosiyi-inajbilshu-geopolitichnukatastrofu-hh-stolittya (Access date: 12.02.2020).

6. Todua Z.D. Rossiya v Moldavii: vernut initsiativu. Rossiya v globalnoy politike. Moskva. 2007. № 1. C. 154-162.

7. O grazhdanstve Rossiyskoy Federatsii. Federalnyiy zakon ot 31.03.2002, № 62-FZ.

URL: http:/consultant.ru/document/cons_doc_LAW (Access date: 24.05.2020).

8. Putin natyaknuv scho ne proty pryyednuvaty prydnistrovya. URL: http://espreso.tv/news/2014/04/17

/putin_natyaknuv_scho_ne_proty_pryyednuvaty_prydnistrovya (Access date: 30.01.2020).

9. Prydnistrovya prositsya v Rosiyu. URL: http://www.pravda.com.ua/news/2014/03/18/7019364/

(Access date: 25.03.2020). 
10. Pridnestrove obratilos k Rossii za priznaniem. URL: http://tiras.ru/tema-dnja/40150-pridnestroveobratiloskrossii-za-priznaniem-i-prisoedineniem-k-rossii.html (Access date: 25.04.2020).

11. Gamova Svetlana. Kusok Moldavii uhodit v sobstvennost Rossii. URL: http://www.ng.ru/cis/2006-04-17 /1_moldavia.html (Access date: 27.04.2020).

12. Nantoy Oazu. Pridnestrovskiy konflikt i vzaimootnosheniya Moldovyi i Ukrainyi. Kontekst. 2001. № 10. C. 22-34.

13. Perepelitsya G.M. Voenna bezpeka Ukrayini na mezhi tisyacholit. URL: http://www.niss.gov.ua /book/bezpeka/index.htm (Access date: 19.12.2019).

14. Ne popadite v kapkan, v kotorom ,barahtaetsya Moldova. URL: http://google/arm/s/www.radiosvoboda.org (Access date: 25.05.2020).

\section{Samarets H. I. Russian Federation's policy on Transnistrian conflict. Ukrainian survey}

The article discloses the main foreign policy steps of the Russian Federation in relation to the Republic of Moldova and the Transnistrian region of the Republic of Moldova. The focus of the policy of the Russian Federation on this issue has a clear aim - to keep Moldova, with the help of all available political tools, in the sphere of its geopolitical influence. Russian authorities consider it necessary to keep the situation around Transnistria in a "frozen" state that ensures the control over the foreign policy of the Republic of Moldova and blocking of European and Euro-Atlantic sympathies and aspirations of the Republic of Moldova. The Russian Federation exercises such steps by providing its legitimate military presence in the region as a result of its participation in the peacekeeping operation Transnistrian region of the Republic of Moldova.

The author suggests us to consider steps of Russian foreign policy in relation to the Republic of Moldova and Transnistria, not in a historical context, but through the political, economic, and military aspects of such steps, dividing them into two major groups: The first of them is characterized by the creation and development of the conflict during the stage of armed confrontation with its subsequent maintenance in an active phase until the object of Russia's geopolitical pressure is losing its interests. The second is the completion of the stage of armed confrontation and the transfer of the conflict to the "frozen" stage because of the beginning of a long negotiation process with its subsequent maintenance in such a state for as long as possible.

Taking into account the equal value of the European and Euro-Atlantic choice of the Republic of Moldova and Ukraine, the existence of common border, there is a possibility that the Russian Federation will apply such political tools as were tested in the Transnistrian region of the Republic of Moldova with regard to Ukraine. Obviously there arises the necessity to prevent possible threats to the national security of Ukraine. Also there appears a necessity of preventing the development of the situation of Russian hybrid aggression of the Russian Federation against Ukraine by Ukrainian public authorities concerned.

The comparison of steps taken by the Russian Federation's policy with respect to Ukraine from the outbreak of armed aggression and up to the present time with the Russian Federation's policy regarding the Republic of Moldova and Transnistria makes it possible to determine at which stage of the Russian scenario is Ukraine and predict its development and thereby some countermeasures.

Key words: Transnistrian region of the Republic of Moldova, the Russian Federation, foreign policy, national security of Ukraine. 